BUSINESS

\title{
Fever pitch
}

\section{The push for new anti-inflammatory drugs has pharmaceutical companies flocking to a previously abandoned therapy. Heidi Ledford reports on the resurrection of interleukin-1 blockers.}

n 1977, researchers isolated a novel protein from human blood that had been exposed to a pathogenic bacterium. Some called the protein a pyrogen because it triggered fever; others called it an activating factor for its ability to stimulate white blood cells. It also damaged joints and influenced liver proteins. Many were sceptical that it was just one protein.

"People didn't believe that a single molecule could do all these things," says Charles Dinarello, an immunologist at the University of Colorado at Denver and one of the first to study the protein, which was eventually called interleukin-1. "I was ridiculed quite a bit."

Thirty years later these arguments are long settled, but the list of functions for interleukin-1 continues to grow. It is now blamed for destroying insulin-producing cells in diabetics and triggering inflammation in Alzheimer's disease. Inhibitors of interleukin-1 are credited with easing the symptoms of rheumatoid arthritis and gout, and alleviating a serious hereditary inflammatory disease.

So it is hardly surprising that the protein is attracting the attention of companies ranging from Swiss pharmaceutical giant Novartis to pharmaceutical antibody developer Xoma, in Berkeley, California, which has just 300 employees. But while the potential market for interleukin-1 blockers now looks bright, many of these companies abandoned previous interleukin-1 programmes years ago.

"The drug companies more or less gave up on interleukin-1."

\section{- Jürg Tschopp}

"The drug companies more or less gave up on interleukin-1," says Jürg Tschopp, an immunologist at the University of Lausanne, Switzerland. "But recently, every drug company I know has reactivated their programme."

That may be because drug firms see a pressing need for additional anti-inflammatory therapies. Non-steroidal anti-inflammatory drugs such as aspirin and COX-2 inhibitors come with unwanted side effects, including gastrointestinal bleeding and, in the case of some COX-2 inhibitors, an increased risk of heart attack and stroke. Another class of antiinflammatory drugs inhibits the inflammationinducing protein tumour necrosis factor alpha (TNF- $\alpha$ ). These inhibitors are prescribed to treat chronic inflammatory conditions such as rheumatoid arthritis and inflammatory bowel it's gone." disease. Sales of the top three TNF-a inhibitors reached US $\$ 10$ billion in 2006.

But TNF- $\alpha$ inhibitors also heighten the risk of opportunistic infections, and simply don't work for some patients, including up to $30 \%$ of those with rheumatoid arthritis. "Everybody has focused on TNF- $\alpha$ for the past ten years," says Raymond Dionne, a pharmacologist at the US National Institutes of Health (NIH) in Bethesda, Maryland. "A lot of people swear by it, but really wish that something else was available."

\section{Left on the shelf}

It was the TNF- $\alpha$ inhibitors that silenced interleukin-1 research programmes nearly a decade ago. Amgen, a biotechnology company headquartered in Thousand Oaks, California, inherited an early formulation of an interleukin-1 inhibitor when it bought a smaller biotech company. Amgen would eventually shape that drug into Kineret (anakinra) - the only interleukin-1 inhibitor currently on the market. But by the time Amgen turned its attention to Kineret, TNF- $\alpha$ inhibitors were showing promise, says rheumatologist Alan Solinger, who oversaw Amgen's clinical trials for both Kineret and the company's TNF-a blocker Enbrel (etanercept) when he worked for the company. He is now vice-president of clinical immunology at Xoma. "The predecessor to Kineret sat on the shelves for about four years before Amgen realized it had an asset that could be developed," says Solinger. "By then, the TNF agents had already moved ahead."

Kineret is a recombinant form of a protein naturally produced by the body to keep interleukin-1 in check by preventing it binding to its receptor. Clinical trials showed that the drug performed well against rheumatoid arthritis and caused no side effects. But Kineret requires a daily injection and it is not an ideal interleukin-1 blocker. "This drug is very short lived," says Tschopp. "You inject it and

Trials showed that TNF- $\alpha$ inhibitors outperformed Kineret in treating rheumatoid arthritis, but some say that this comparison unfairly weakened the general case for interleukin-1 blockers. "Enbrel and the others were excellent TNF blockers, but Kineret was not as

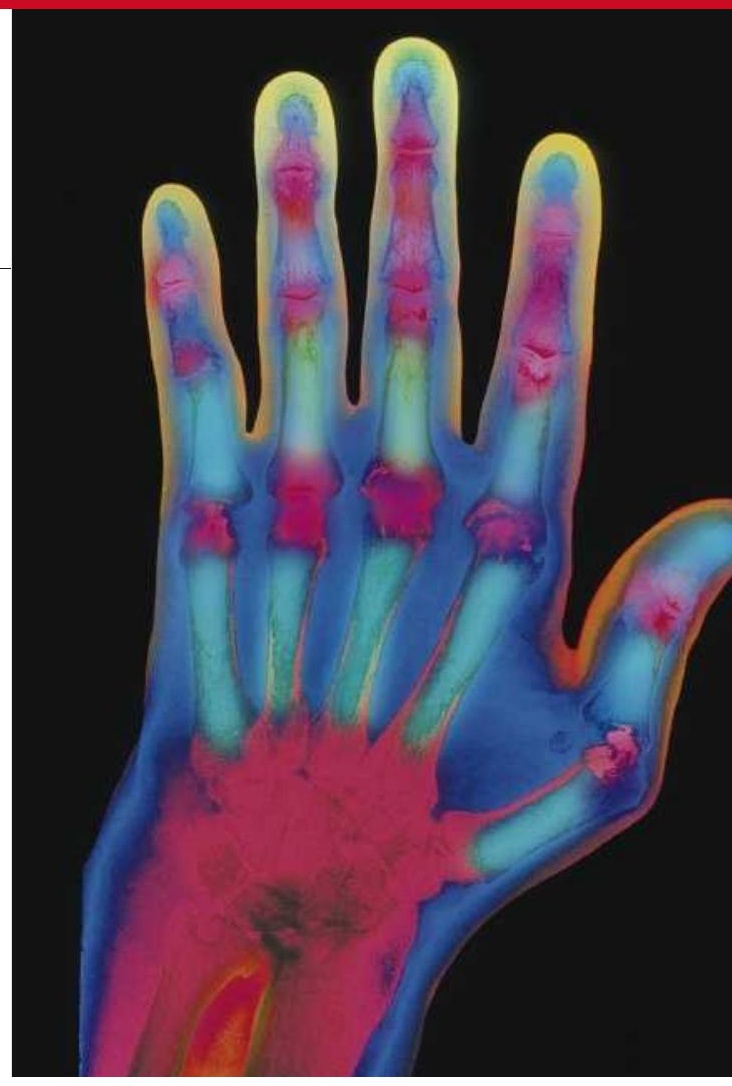

Rheumatoid arthritis is a potential target for the next generation of interleukin-1 blockers.

good an interleukin-1 blocker," says Solinger. "Everybody moved over to the TNF bandwagon, including Amgen."

The US Food and Drug Administration (FDA) approved Kineret in November 2001. A month later, Amgen announced its acquisition of Immunex, the creators of Enbrel. Over time, Amgen shifted money away from marketing Kineret and focused on Enbrel, which generated almost $\$ 3$ billion in 2006 sales, making it one of Amgen's top three products.

Although commercial interest faded, research still pointed to the medical importance of interleukin-1. Its processing into a mature protein requires the activation of a protein complex called the inflammasome. Tschopp and his colleagues found that the inflammasome is activated by the uric acid crystals that accumulate in the joints of patients with gout ${ }^{1}$, and a small clinical trial showed that Kineret provided quick relief to those suffering an acute attack of gout.

Other researchers have linked a hereditary inflammatory illness called neonatal-onset multisystem inflammatory disease to the inflammasome. Another small clinical trial showed that Kineret relieved symptoms of this disease, including hearing loss, brain lesions and rashes ${ }^{2}$. More recently, Kineret was shown to partially relieve the symptoms of type 2 diabetes $^{3}$. And animal studies have suggested that type 2 diabetes may respond to interleukin- 1 blockade but not to TNF- $\alpha$ inhibitors.

Kineret itself has not proved popular, however, despite the promising trials. "No one cares about Kineret," says Eric Schmidt, an analyst at investment bankers Cowen and Company, 


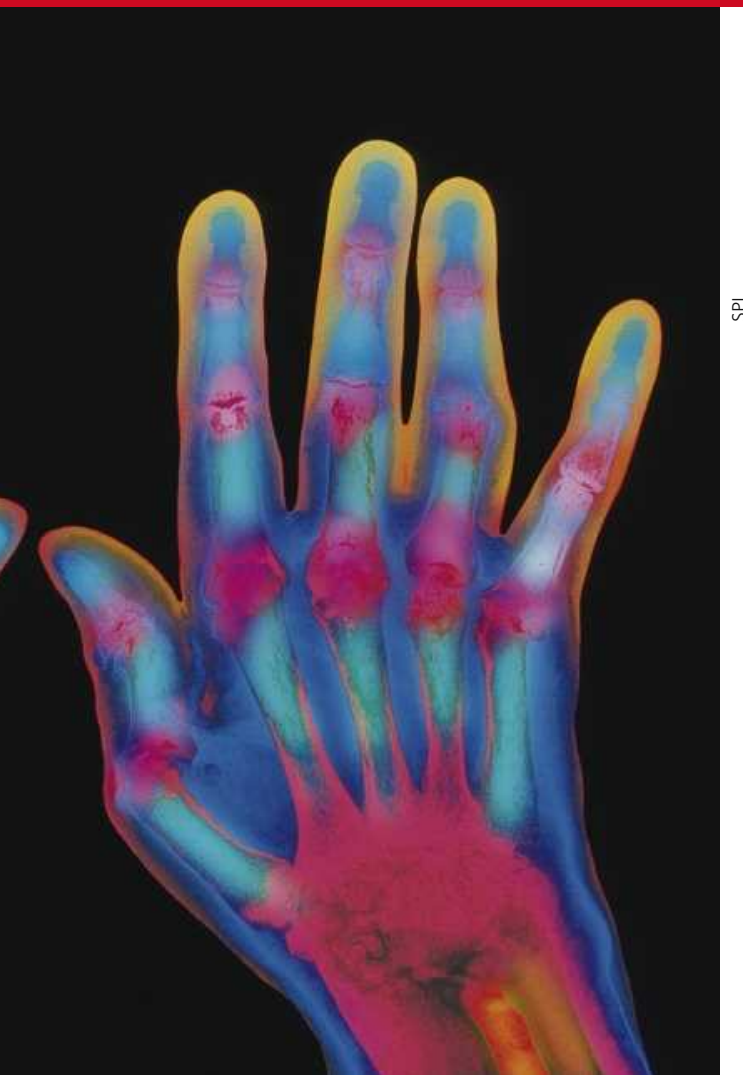

based in New York. "Maybe that's not reflective of the value of this pathway. Maybe Kineret is constrained by daily dosing. But it's just not competitive."

\section{Trials race}

Instead, companies are racing to make new interleukin-1 blockers. Amgen has an antiinterleukin-1 antibody in phase II clinical trials for rheumatoid arthritis. Novartis, which abandoned its first interleukin-1 project in 2000, now has an anti-interleukin-1 antibody in phase III trials for treatment of a rare inflammatory disorder called Muckle-Wells syndrome and phase II trials for rheumatoid arthritis. Previous trials showed remission of Muckle-Wells syndrome for up to six months after a single injection of antibody.

Several smaller biotech companies have also entered the fray. Regeneron, based in Tarrytown, New York, submitted a biologics licence application to the FDA in May for its interleukin-1 blocker Rilonacept (IL-1 Trap) for treatment of Muckle-Wells syndrome and another inherited inflammatory disorder. And Xoma is testing an anti-interleukin-1 antibody in phase I studies in patients with type 2 diabetes.

For Solinger, bringing a viable interleukin-1 therapy to market would be the culmination of a long scientific odyssey. Thirty years ago, he worked down the hall from the NIH laboratory in which Dinarello first purified the 'activating factor.' "That's one reason why I'm excited about this," he says. "Fairly soon we should know if we have a winner or not."

1. Martinon, F. et al. Nature 440, 237-241 (2006).

2. Goldbach-Mansky, R. et al. N. Engl. J. Med. 355, 581-592 (2006).

3. Larson, C. M. et al. N. Engl. J. Med. 356, 1517-1526 (2007).

\section{IN BRIEF}

EUROPE SAYS NO Regulators have indicated that two strains of genetically modified maize (corn) are unlikely to receive approval for commercial cultivation in the European Union (EU) - setting back seed companies' hopes of a more liberal regulatory environment for genetically modified agriculture in Europe. EU environment commissioner Stavros Dimas said on 22 November that the two strains, insect-resistant Bt 11 from Syngenta and insect- and herbicide-resistant corn 1507, sold by Dow and Pioneer, would be rejected on the grounds of their possible adverse impact on butterflies and other insects.

BIOTECH BUY British drug company GlaxoSmithKline is to buy Reliant, a New Jersey biotechnology company that specializes in cardiovascular medicines, for US $\$ 1.65$ billion. The agreed sale, announced on 21 November, means that Reliant will cancel a plan, announced in August, for an initial public stock offering. Analysts say that the move the latest in a string of large biotechnology purchases by major drug companies this year - reflects Glaxo's need to line up new revenue streams in the wake of reported safety problems that are hitting sales of its diabetes drug Avandia.

ROAD TEST Daimler says it will put 100 prototypes of its new Smart Fortwo plug-in allelectric cars on the streets of London by the end of this year, as part of a plan to test the feasibility of the vehicles. The cars will initially run off nickel hydride batteries, but will switch to lithium ion ones as they become available, company officials told the Financial Times. The cars will have a range of $110 \mathrm{~km}$ and take three-and-a-half hours to recharge, the official added. The German car maker hopes to start commercial production by 2010.

\section{MARKET WATCH}

\section{NANOTECHNOLOGY STOCKS}

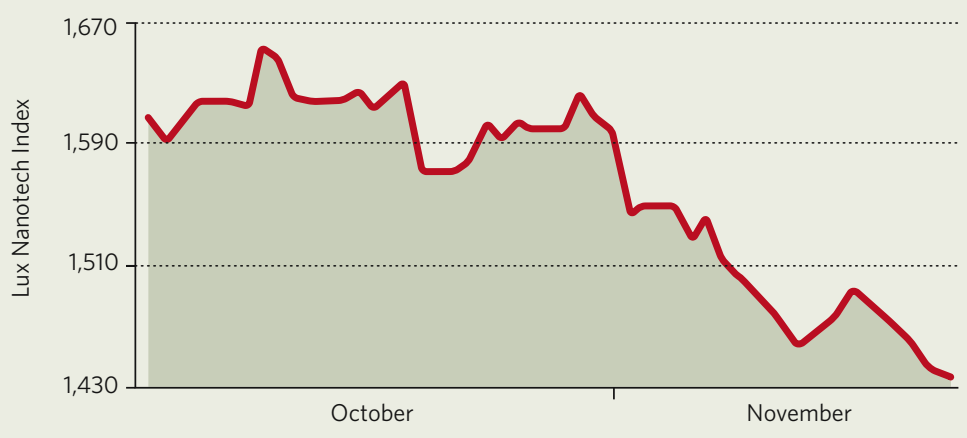

With the collapse of both the dollar and the housing market undermining confidence about the general economic outlook in the United States, 2007 has been a pretty grim year for technology stocks there. Nanotechnology is no exception, and the Lux Nanotech Index (symbol LUXNI on the American Stock Exchange) is lurching unsteadily towards the end of the year.

The index, which tracks the performance of US companies that supply nanotechnology products and services and of some major industrial corporations that rely heavily on them, has dipped with the rest of the market. Indeed, the index is at the same level now as it was four years ago.

"There's been a lack of any discernible trend" in the market for nanotech stocks in recent months, says Peter Hebert, founder of New York-based Lux Research, which compiles the index.
Hebert says that more and more nanotechnology development is taking place inside the large industrial corporations that use the technology especially in Japan - rather than in small specialist companies. That reflects the strategic importance of nanotechnology to these big companies, but it doesn't do much for the investor seeking to make a quick profit out of a successful technology.

One bright spot was the 1 November initial public offering of stock in Nanosphere, an Illinois-based molecular-diagnostics company. The offering raised US $\$ 98$ million. Hebert calls this "a pretty good achievement" and adds that it is good news for companies such as Harris and Harris, a New York-based venture-capital firm that has backed several dozen small nanotech companies.

Colin Macilwain 